\title{
EVALUASI PROGRAM PENGEMBANGAN ANAK USIA DINI HOLISTIK INTEGRATIF DI SATUAN PAUD
}

\author{
Reza Aulia Akbar \\ Universitas PGRI Palembang \\ Email: budakpgril01@gmail.com
}

Article received: 15 Mei 2018, Review process: 22 Mei 2018

Article published: 30 September 2018

\begin{abstract}
This research aim to evaluate program development of early childhood holistic integratif in early childhood unit and executed of Palembang. Model evaluation which used in this research is CIPP model. As for technique analyse research data use approach of methods mixed, concurrent embedded methods. Technique data collecting use interview, enquette, observation, documentation. Result of analyse conclude 1) the evaluation context express that management of service development of early childhood holistic integratif in unit of education of early childhood represent solution which enough responsive to requirement; 2) the input of evaluation express that there is no program devise development of early childhood clear integratif holistic of government in town start from activity formation till evaluate excecution in unit of early childhood education; 3) the evaluation process express that from entire service aspect, only on duty health through Puskesmas which have run sectoral function; 4) the evaluation product express that management of program not walked as according to guide of execution of program in unit education of age early yet. Its meaning, there is no impact can measured from management of program. From result of researcher evaluation recommend to be reviseing to management of program whicb relate to 1) by law of Palembang 2) regulation of President No. 60 Year 2013, and 3) regulation of Minister No. 59 Year 2009.
\end{abstract}

Keyword: Program Development of Early Childhood Holistik Integratif, Early Childhood Education, Evaluate Program

\section{Abstrak}

Penelitian ini bertujuan untuk mengevaluasi program Pengembangan Anak Usia Dini Holistik Integratif di satuan PAUD dan dilaksanakan di Kota Palembang. Model evaluasi yang digunakan dalam penelitian ini adalah CIPP Model. Adapun teknik analisis data penelitian menggunakan pendekatan mixed methods, Concurrent Embedded Methods. Teknik pengumpulan data menggunakan wawancara, angket, observasi, dokumentasi. Hasil penelitian menyimpulkan 1) context evaluation menyatakan bahwa Penyelenggaraan layanan Pengembangan Anak Usia Dini Holistik Integratif di satuan PAUD Kota Palembang belum memiliki landasan hukum yang kuat. Penyelenggaraan layanan Pengembangan Anak Usia Dini Holistik Integratif di satuan PAUD merupakan solusi yang cukup responsive terhadap kebutuhan, 2) input evaluation menyatakan bahwa belum ada rancangan program Pengembangan Anak Usia Dini Holistik Integratif yang jelas dari Pemkot mulai dari susunan kegiatan hingga evaluasi pelaksanaan di satuan PAUD, 3) process evaluation menyatakan bahwa dari seluruh aspek pelayanan, hanya Dinas Kesehatan melalui Puskesmas yang telah menjalankan fungsi 
sektoralnya, 4) product evaluation menyatakan bahwa penyelenggaraan program belum berjalan sesuai dengan petunjuk pelaksanaan program di satuan PAUD. Artinya, belum ada impact yang dapat diukur dari penyelenggaraan program. Dari hasil evaluasi peneliti merekomendasikan agar ada revisi terhadap penyelenggaraan program yang mengacu pada 1) Perda Kota Palembang; 2) Perpres No 60 Tahun 2013, dan 3) Permen No 59 Tahun 2009.

Kata Kunci : Anak Usia Dini, Holistik Integratif, PAUD, Evaluasi Program.

\section{PENDAHULUAN}

Penelitian ini dilatarbelakangi oleh Perpres No 60 Tahun 2013 tentang pemenuhan kebutuhan anak usia dini secara holistik dan integratif serta upaya untuk mengarahkan semua pemangku kepentingan agar dapat memainkan perannya masing masing dan saling melengkapi dalam memastikan pertumbuhan dan perkembangan anak yang sehat (Direktorat Pembinaan Anak Usia Dini, 2015). Perpres No 60 Tahun 2013 pasal 7 ayat (1) menyatakan bahwa penyelenggaraan Pengembangan Anak Usia Dini Holistik Integratif dilakukan oleh Pemerintah, Pemerintah Daerah, dan masyarakat. Kemudian pada ayat (4) menyatakan bahwa pemerintah Kabupaten/Kota bertanggung jawab untuk a) melaksanakan pelayanan pengembangan anak usia dini, b) melakukan bimbingan teknis kepada penyelenggara pelayanan, c) melakukan supervisi atas kegiatan pengembangan anak usia dini, d) melakukan advokasi, e) memberikan pelatihan kepada penyelenggara dan/atau tenaga pelayanan, dan f) melakukan evaluasi dan pelaporan. Kebutuhan esensial anak yang harus dipenuhi melalui program Pengembangan Anak Usia Dini Holistik Integratif mencakup 1) aspek pendidikan; 2) aspek kesehatan dan pemenuhan gizi; 3) aspek pengasuhan dan keamanan, serta; 4) aspek kesejahteraan. Kemudian seluruh aspek ini saling terkait secara simultan, sistematis, dan terintegrasi antar sektor.

Dalam Petunjuk Teknis Penyelenggaraan Pengembangan Anak Usia Dini Holistik Integratif di satuan PAUD (2015) menyatakan bahwa instansi Pemerintah dan masyarakat sebagai pihak yang terkait dalam penyelenggaraan Pengembangan Anak Usia Dini Holistik Integratif, antara lain 1) Satuan PAUD; 2) Dinas Pendidikan; 3) Dinas Kesehatan; 4) Dinas Sosial; 5) BKKBN; 6) Dinas Kependudukan dan Catatan Sipil; 7) Badan Pemberdayaan Masyarakat; 8) Polres dan Polsek; 9) organisasi mitra; 10) Posyandu; 11) tokoh masyarakat; dan 12) orang tua.

Adapun pertimbangan dan landasan Pemerintah menyelenggarakan Pengembangan 
Anak Usia Dini Holistik Integratif antara lain 1) bahwa sumber daya manusia yang sehat, cerdas, dan produktif merupakan aset yang sangat berharga bagi bangsa dan negara Indonesia; 2) bahwa peningkatan kualitas sumber daya manusia dalam pencapaian tumbuh kembang optimal sangat ditentukan oleh kualitas perkembangan anak selama periode usia dini yaitu sejak janin sampai anak berusia 6 (enam) tahun yang terlihat dari meningkatnya derajat kesehatan dan status gizi, kecerdasandan keceriaan, pematangan emosional dan spiritual, dan kesejahteraan anak, dan 3) bahwa untuk menjamin pemenuhan hak tumbuh kembang anak usia dini, diperlukan upaya peningkatan kesehatan, gizi, perawatan, pengasuhan, perlindungan, kesejahteraan, dan rangsangan pendidikan yang dilakukan secara simultan, sistematis, menyeluruh, terintegrasi, dan berkesinambungan (Perpres No 60 Tahun 2013).

Pertimbangan tersebut, jelas menyatakan bahwa pemenuhan seluruh aspek kebutuhan anak usia dini adalah faktor penting dalam upaya peningkatan kualitas sumber daya manusia di Indonesia. Karena itu, memulai pembinaan baru pada usia taman kanak-kanak (TK) sudah dipandang terlambat (Rahardjo, 2006), di mana perkembangan kecerdasan anak mencapai 50\% pada usia 0-4 tahun, $80 \%$ pada usia 4-8 tahun, dan 100\% pada usia 8-18 tahun. Sedangkan pertumbuhan fisik anak usia 0 tahun mencapai $25 \%, 6$ tahun mencapai $90 \%$, dan 12 tahun mencapai 100\% (Osbon, White, dan Bloom, 2004), dan 50 \% kemampuan kognitif seseorang terbentuk pada usia 0-4 tahun. Karena itu, intervensi perkembangan anak sejak dini punya pengaruh jangka panjang terhadap kemampuan dan perkembangan intelektual, sosial, dan kepribadian seseorang dalam perkembangan selanjutnya (Siswanto, 2014).

Dengan demikian, pendidikan anak usia dini tidak dapat dilaksanakan secara tersendiri dengan hanya satu aspek yang diajarkan tetapi memerlukan perpaduan dari beberapa aspek kebutuhan anak yang terintegrasi agar anak dapat tumbuh dan berkembang menjadi anak yang sehat, cerdas, ceria dan berakhlak mulia. Dengan cara ini, tujuan PAUD untuk membentuk anak yang berkualitas, anak yang tumbuh dan berkembang sesuai dengan tingkat perkembangannya sehingga memiliki kesiapan yang optimal di dalam memasuki pendidikan dasar serta mengarungi kehidupan di masa dewasa (Tedjawati, 2011) akan tercapai dengan maksimal apabila kebutuhan esensial anak usia dini tidak terpenuhi. Pendapat di atas didukung oleh penelitian yang dilakukan oleh Diana, Symon \& Yurizal, (2011) yang menyatakan bahwa semakin rendah status gizi anak maka semakin tinggi keterlambatan perkembangannya. Kemudian penelitian oleh Husaini (2003) mengemukakan bahwa anak 
dengan status gizi buruk cenderung lebih banyak terhambat perkembangan motorik kasamya (25\%) dan 8 kali lebih basar kemungkinan terlambat perkembangan motorik kasarnya dibandingkan anak yang berstatus gizi normal, dan 90\% dari pertumbuhan otak terjadi pada dua tahun pertama kehidupannya dan sangat bergantung pada gizi yang diperolehnya.

Konsep penyelenggaraan Pengembangan Anak Usia Dini Holistik Integratif di satuan PAUD sejalan dengan penelitian yang dilakukan oleh Sabarini, Zahraini \& Dewi (2013) yang mengemukakan bahwa desain penyelenggaran holistik integratif yang diterapkan di satuan PAUD dengan bina keluarga balita dan Posyandu juga sangat efektif dibandingkan dengan pelayanan yang hanya dilakukan oleh posyandu atau bina keluarga balita secara mandiri.

Kota Palembang memiliki 666 satuan PAUD yang memiliki Nomor Pokok Sekolah Nasional (Dinas Pendidikan Kota Palembang, 2017) dan terdapat 633 lembaga yang terdata pada data pokok pendidik (Dapodik) (Palembang HS, November 2016). Dari 666 satuan PAUD hanya 90 PAUD tercatat sebagai PAUD yang berstatus terakreditasi. (Dinas Pendidikan Kota Palembang, 2017). Kemudian, dari seluruh satuan PAUD, hanya 534 satuan PAUD yang terafiliasi dengan Puskesmas pada masing masing Kecamatan (Dinas Kesahatan Kota Palembang, 2016).

Dari data di atas, ada 534 satuan PAUD telah terafiliasi dengan Puskesmas, akan tetapi, dari hasil observasi yang dilakukan oleh peneliti selama melakukan penelitian ini, peneliti melihat bahwa subtansi layanan yang diselenggarakan oleh satuan PAUD Kota Palembang sebagian besar masih spesifik mengarah pada konteks pendidikan saja. Hal ini, tentu tidak sejalan dengan apa yang di rumuskan dalam Permen No 58 Tahun 2009 di mana di dalam Sub II Standar Tingkat Pencapaian Perkembangan Anak menyatakan bahwa agar anak mencapai tingkat perkembangan yang optimal, dibutuhkan keterlibatan orang tua dan orang dewasa untuk memberikan rangsangan yang bersifat menyeluruh dan terpadu yang meliputi pendidikan, pengasuhan, kesehatan, gizi, dan perlindungan yang diberikan secara konsisten melalui pembiasaan.

Kondisi ini, dapat mengindikasikan bahwa ada Pengembangan Anak Usia Dini belum terselenggara dengan maksimal. Indikasi ini kemudian didukung oleh temuan peneliti bahwa belum adanya garis komunikasi yang jelas dan integratif antara satuan PAUD Kota Palembang dengan instansi terkait penyelengaraan layanan Pengembangan Anak Usia Dini Holistik Integratif. Dengan demikian, maka peneliti menilai perlu untuk dilakukan evaluasi 
terhadap program Pengembangan Anak Usia Dini Holistik Integratif di satuan PAUD kota Palembang.

Dengan penelitian evaluasi ini, peneliti dapat menyajikan data tentang keterbutuhan satuan PAUD terhadap program, perencanaan program, keterlaksanaan program, sejauh mana program ini memberikan manfaat, dan dampak positif dan responsif bagi masyarakat di Kota Palembang. Kemudian, hasil evaluasi ini diharapkan dapat menjadi informasi, akuntabilitas, masukan, serta bahan pertimbangan bagi pengambil kebijakan terkait pelaksakanaan program Pengembangan Anak Usia Dini Holistik Integratif di satuan PAUD Kota Palembang. Fokus evaluasi ini diberikan kepada Pemerintah Kota, artinya hasil penelitian ini bertujuan untuk memberikan informasi bagi Pemerintah Kota Palembang sebagai bahan pertimbangan untuk mengambil keputusan apakah program ini dilanjutkan, direvisi, atau dihentikan.

\section{METODOLOGI}

Penelitian ini menggunakan desain mixed methods, concurrent embedded methods (Creswell, 2012). Sedangkan metode yang digunakan dalam penelitian ini adalah metode evaluasi. Secara kualitatif, penelitian ini diharapkan mampu menggambarkan keadaan yang sebenarnya (naturalistik) di lapangan. Sementara secara kuantitatfif, dapat digunakan untuk mendukung analisis kualitatif. Model evaluasi yang digunakan dalam penelitian ini adalah CIPP model (Context, Input, Process dan Product). CIPP model memiliki komponen khusus dalam evaluasi yaitu context, input, process dan product (Stufflebeam, 1985). Penelitian ini dilaksanakan di satuan PAUD Kota Palembang. Waktu penelitian dilakukan oleh peneliti dimulai pada tanggal 01 Juni 2017 sampai 15 Januari 2018. Tehnik pengambilan sampel pada penelitian ini menggunakan dua teknik pengambilan sampel yaitu 1) Purposive sampling (non probability sample); 2) Simple Random sampling (probability sample). Teknik ini digunakan karena menimbang dalam penelitian ini populasinya sangat laus dan desain penelitian yang menggunakan mixed methods.

Pemilihan teknik pengambilan sampel pertama yang dilakukan untuk penelitian ini adalah dengan teknik non probabality sample dengan metode Purposive Sampling. Karena luasnya responden di dalam penelitian ini maka peneliti mengambil orang tua anak usia dini yang berjumlah 76 orang yang terdiri dari orang tua anak usia dini yang bersekolah di PAUD KB Anak Emas Kecamatan Kertapati Palembang, PAUD RA Purwanida IV Jakabaring, dan TK Pembina I Kecamatan IB I Palembang. Kemudian peneliti mengambil responden berupa 
tokoh kunci (key person) yang dipercaya dan dianggap bisa mewakili sasaran serta tujuan penelitian yang terdiri dari 2) pengelola dan kepala sekolah PAUD Kota Palembang, 3) HIPAUDI Kota Palembang, dan 4) ahli dan praktisi PAUD Kota Palembang.

Cara lain yang digunakan untuk mengambil sampel dalam penelitian ini adalah dengan menggunakan metode simple random sampling yaitu teknik pengambilan sampel dengan cara acak (Kesumawati, Retta \& Sari, 2017: 12). Terdapat 534 satuan PAUD yang terafiliasi dengan Puskesmas pada tiap kecamatan di Kota Palembang yang dapat dijadikan asumsi awal bahwa satuan PAUD tersebut telah melaksanakan layanan Pengembangan Anak Usia Dini Holistik Integratif, maka sampel dalam penelitian ini adalah 10\% dari 534 satuan PAUD yaitu 53 satuan PAUD Kota Palembang sebagai sampel penelitian.

Teknik pengumpulan data dalam penelitian ini menggunakan pendekatan appreciative inquiry (AI) sebagai pendekatan dalam pengumpulan informasi karena fokus yang kuat dari AI adalah untuk membangun kekuatan yang telah ada dari pada membuat daftar masalah (Bappenas, 2013: 1). Tujuan dari peneliti dengan menggunakan pendekatan ini adalah untuk mengarahkan penelitian ini kepada sejauhmana pencapaian program Pengembangan Anak Usia Dini Holistik Integratif ini. Kemudian, pencapaian tersebut dapat dijadikan dasar dari upaya pemerintah dan seluruh pihak yang terkait pelaksanaan layanan Pengembangan Anak Usia Dini Holistik Integratif untuk melaksanakan layanan ini dengan maksimal.

Adapun teknik pengumpulan data pada penelitian ini menggunakan instrument penelitian yaitu (1) observasi, tujuan observasi dalam penelitian ini adalah untuk mendapatkan pemahaman mengenai kondisi satuan PAUD dan melihat lebih dalam rutinitas dari keseharian yang dapat di jadikan informasi; (2) wawancara, wawancara dilakukan kepada masyarakat, satuan PAUD (pendidik, tenaga pendidik, pengelola PAUD), narasumber pada setiap instansi terkait penyelenggaraan program seperti Dinas Kesehatan, Dinas Sosial, Polri, dan Pemerintah Daerah sebagai penanggungjawab program Pengembangan Anak Usia Dini Holistik Integratif. Dalam penelitian ini, wawancara dilakukan oleh peneliti dengan format terstruktur, dan tidak terstruktur. Kemudian wawancara dilaksanakan sesuai dengan waktu yang ditentukan oleh informan; (3) angket, pada teknik ini, peneliti mengumpulkan data dengan instrumen yang telah disusun berdasarkan Petunjuk Teknis Penyelenggaraan Pengembangan Anak Usia Dini Holistik Integratif di satuan PAUD Tahun 2015. Pengumpulam data lewat angket dilakukan untuk mengetahui karaktersitik dari pencapaian 
pelaksanaan program Pengembangan Anak Usia Dini Holistik Integratif (procees evaluation) yaitu mencakup 1) pelayanan; 2) bimbingan; 3) advokasi; 4) evaluasi; dan 5) tindak lanjut; (4) dokumentasi, dokumentasi dalam penelitian ini bertujuan agar peneliti dapat mengambil sebanyak banyaknya data bersifat fisik mengenai program Pengembangan Anak Usia Dini Holistik Integratif di satuan PAUD yang dapat di gunakan untuk menguatkan analisa dalam penelitian evaluasi ini.

Teknik analisis data menggunakan teknik analisis kualitatif dan kuantitatif. Adapun analisa data meliputi komponen CIPP Model penelitian, yaitu: context evaluation, input evaluation, process evaluation, dan product evaluation. Teknik analisis data dalam penelitian ini adalah sebagai berikut: (1) Analisis Data Kualitatif, teknik analisis data kualitatif dalam penelitian ini menggunakan analisis Miles dan Huberman (1986) yang didasarkan pada tiga komponen utama yang meliputi reduksi data (data reduction), penyajian data (data display), dan penarikan kesimpulan (verifikasi). Mengingat bahwa setiap kegiatan evaluasi paling sedikit selalu megandung 3 (tiga) komponen utama, yaitu: data, kriteria, dan judgment, maka diskripsi data dalam penelitian ini disajikan dengan proses analisis yang dilakukan oleh peneliti (evaluator) dan dibandingkan dengan kriteria program; (2) Analisis Data Kuantitatif, teknik analisis data kuantitatif dalam penelitian ini, yaitu dengan menggunakan teknik analisis statistik deskrifitf dengan menggunakan sofwer SPSS 20.00 untuk menganalisis data process evaluation.

\section{HASIL PENELITIAN DAN PEMBAHASAN}

\section{Context Evaluation}

Context evaluation dalam penelitian ini bertujuan untuk mengetahui apakah penyelenggaraan program Pengembangan Anak Usia dini di satuan PAUD Kota Palembang memiliki landasan formal yang kuat serta apakah program Pengembangan Anak Usia Dini Holistik Integratif dinilai responsif terhadap permasalahan yang ada di satuan PAUD Kota Palembang. Dari hasil wawancara dengan Dr. Hj. Sri Sumiati, SH. M.Hum, Praktisi Hukum, Dosen Pascasarjana Prodi Hukum S2 Universitas Muhammadiyah Palembang (UMP), Kaprodi SI Hukum Tata Negara UMP yang mengemukakan bahwa program Pengembangan Anak Usia Dini Holistik Integratif memiliki dasar hukum yang kuat yaitu Permen No 60 Tahun 2013. Selama belum ada Perpres pengganti yang merevisi Perpres tersebut maka Perpres No 60 Tahun 2013 tersebut tetap berlaku dan harus dilaksanakan (Hasil Wawancara 
Tanggal 12 Oktober 2017). Dari hasil wawancara tersebut, maka Pengembangan Anak Usia Dini Holistik Integratif harus dilaksanakan oleh Pemerintah Kota Palembang sebagaimana yang dicantumkan dalam Perpres No 60 Tahun 2013 Pasal 7 ayat 1 yang menyatakan bahwa penyelenggaraan Pengembangan Anak Usia Dini Holistik Integratif dilakukan oleh Pemerintah, Pemerintah Daerah, dan masyarakat. Artinya Pemerintah Kota Palembang memiliki kewajiban untuk menyelenggarakan program Pengembangan Anak Usia Dini Holistik Integratif sesuai dengan amanah di dalam Perpres No 60 Tahun 2013.

Pernyataan di atas, menegaskan bahwa penyelenggaraan program Pengembangan Anak Usia Dini holistik integratif sudah memiliki landasan hukum yang kuat, akan tetapi penyelenggaraan program Pengembangan Anak Usia Dini Holistik Integratif di satuan PAUD belum memiliki landasan formal yang kuat karena acuan penyelenggaraan program Pengembangan Anak Usia Dini Holistik Integratif di satuan PAUD belum spesifik di atur di dalam Perpres tersebut dan belum ada Perda yang mengatur teknis penyelenggaraan program di satuan PAUD Kota Palembang. Dr. Hj. Sri Sumiati, SH. M.Hum, Praktisi Hukum, Dosen Pascasarjana Prodi Hukum S2 Universitas Muhammadiyah Palembang (UMP) mengemukakan apabila teknis penyelengaraan Program Pengembangan Anak Usia Dini Holistik Integratif di satuan PAUD belum diatur secara detail dalam Perpes No 60 Tahun 2013, Pemerintah Kota Palembang dapat menerbitkan Perda yang mengatur teknis penyelengaraan program Pengembangan Anak Usia Dini Holistik Integratif di satuan PAUD khususnya koordinasi antara tiap tiap instansi terkait penyelenggaraan layanan program (Hasil Wawancara Tanggal 12 Oktober 2017). Tetapi saat ini, Pemerintah Kota Palembang belum memiliki Perda yang mengatur teknis penyelenggaraan program di satuan PAUD Kota Palembang. Peneliti menilai berdasarkan Perpres tersebut, Pemerintah Kota Palembang tetap memiliki kewajiban untuk menyelengarakan program Pengembagan Anak Usia Dini Holistik Integratif dan harus mengeluarkan Perda terkait penyelenggaraan program.

Kemudian program Pengembangan Anak Usia Dini Holistik Integratif dinilai responsif terhadap kebutuhan masyarakat KOTA Palembang. Berdasarkan hasil wawancara peneliti dengan ibu Erna Ningsih, S.Pd AUD, Kepala Sekolah PAUD TK Pembina 1 Kota Palembang, beliau menyatakan bahwa umumnya espektasi masyarakat kepada PAUD adalah sebagai tempat untuk belajar membaca, menghitung, dan menulis, agar anaknya dapat diterima di sekolah yang masih memakai kebijakan persyaratan tidak tertulis yaitu anak harus 
mampu membaca, menghitung, dan menulis untuk masuk sekolah (Hasil Wawancara Pada Tanggal 9 Desember 2017). Hasil wawancara di atas, didukung oleh hasil wawancara peneliti pada tanggal 16 sampai 20 Desember 2017 kepada 76 orang tua anak yang bersekolah di satuan PAUD Kota Palembang sebagai responden penelitian. Peneliti menemukakan bahwa $57,89 \%$ tujuan orang tua menjawab bahwa mereka menyekolahkan anaknya di satuan PAUD agar anaknya pandai membaca, menulis, dan menghitung dan 23,69\% tujuan orang tua adalah agar anaknya memiliki kemandirian, kemudian 5,26\% menginginkan anaknya mampu beradaptasi, dan 13,16\% mengharapkan anaknya dapat memiliki karakter positif. Adapun hasil wawancara tersebut dapat dilihat pada diagram berikut ini.

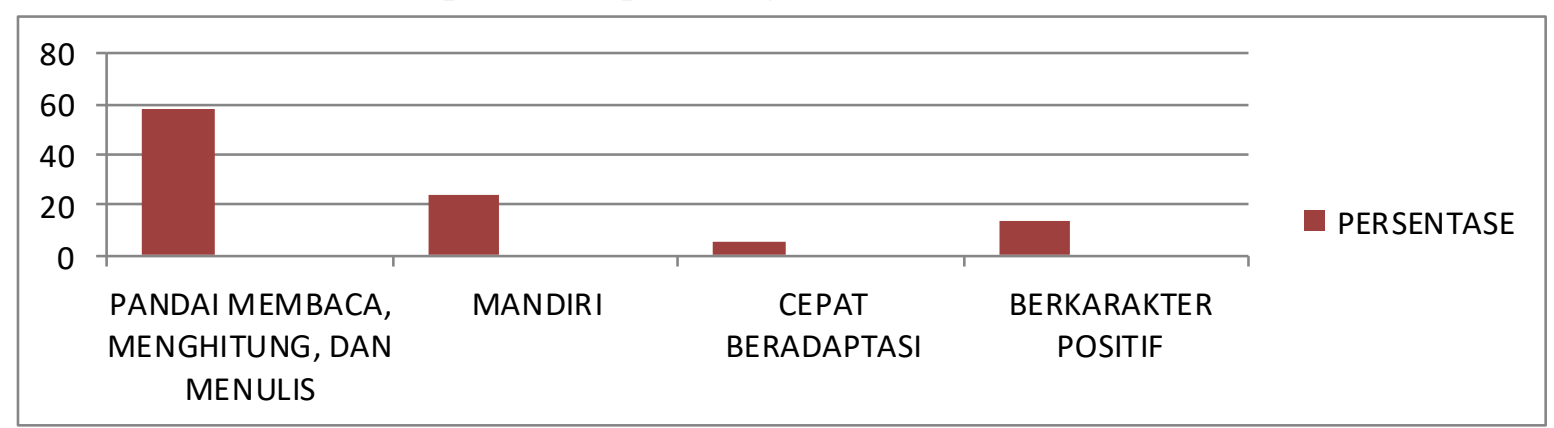

\section{Gambar 1. Diagram Persepsi Orang Tua Terhadap Satuan PAUD Kota Palembang}

Kemudian wawancara selanjutnya menyatakan bahwa $69.8 \%$ orang tua menginginkan anaknya berprestasi di bidang akademik setelah menempuh pendidikan di satuan PAUD Kota Palembang dan 6,6\% orang tua menginginkan anaknya cepat beradaptasi di sekolah lanjutan setelah menempuh pendidikan di satuan PAUD Kota Palembang, kemudian 2,7\% menginginkan anaknya memiliki kemandirian dan displin setelah menempuh pendidikan di satuan PAUD, dan 21,1\% mengharapkan anaknya dapat memiliki kepercayaan diri yang tinggi setelah menempuh pendidikan di satuan PAUD. Adapun hasil wawancara tersebut dapat dilihat pada diagram berikut ini.

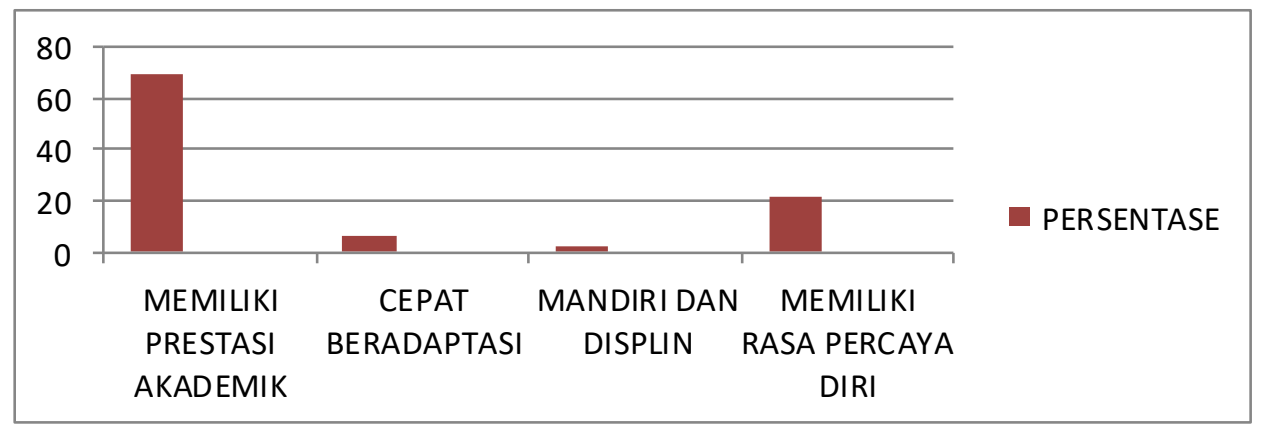

Gambar 2. Diagram Persepsi Orang Tua Terhadap Satuan PAUD Kota Palembang 
Dari hasil wawancara di atas, maka dapat diketahui bahwa tuntutan masyarakat serta beberapa lembaga Pendidikan Dasar, menjadikan lembaga PAUD harus menjadi lembaga yang mampu menjawab tuntutan tersebut. Maka, untuk menghasilkan output yang sesuai dengan tuntutan masyarakat tersebut, idealnya anak harus memiliki kesehatan yang baik, pengasuhan yang baik, keamanan yang memadahi, serta tingkat kesejahtreraan yang baik. Oleh karena itu, untuk mendapatkan hasil maksimal, satuan PAUD harus menyelengarakan layanan Pengembangan Anak Usia Dini Holistik Integratif dan diperlukan dukungan dari setiap sektor yang mampu menjadikan satuan PAUD sebagai layanan yang mampu untuk mamenuhi seluruh aspek kebutuhan anak usia dini dan pada akhirnya layanan PAUD mampu untuk mencapai tujuannya dengan maksimal.

Program Pengembangan Anak Usia Dini Holistik Integratif memang idealnya dilaksanakan di satuan PAUD menimbang bahwa satuan PAUD merupakan hilir dari tujuan Pengembangan Anak Usia Dini Holistik Integratif, yaitu kesiapan anak untuk melanjutkan pendidikan kejenjang selanjutnya. Kemudian satuan PAUD dalam praktik layanan sehari hari telah menerapkan konsep dasar layanan Pengembangan Anak Usia Dini Holistik Integratif, seperti pendidikan kesehatan bagi anak, pendidikan keamanan dan kesahteraan bagi anak. Sebagian TK di Kota Palembang memiliki program rutin dalam melaksanakan penyuluhan kepada orang tua. Materi penyuluhan tersebut kurang lebih berkaitan dengan peran serta orang tua untuk mendukung program layanan TK Pembina 1 Palembang, adapun narasumber dalam kegiatan penyuluhan di ambil dari orang tua anak yang berpropesi sebagai dokter, polisi dan lain lain (Hasil wawancara pada tanggal 9 Desember 2017 dengan ibu Erna Ningsih, S.Pd AUD, Kepala Sekolah PAUD TK Pembina 1 Kota Palembang)

Dengan demikian dapat dijelaskan bahwa satuan PAUD merupakan lembaga yang sebenarnya sudah memiliki basis dasar dalam penyelenggaraan Pengembangan Anak Usia Dini yang holistik, meskipun unsur integratif belum terlaksana dengan maksimal. Dengan demikian, program Pengembangan Anak Usia Dini Holistik Integratif adalah program yang dinilai responsif terhadap permasalahan yang ada di satuan PAUD Kota Palembang yaitu tuntutan masyarakat agar satuan PAUD sebagai satuan pendidikan harus mampu menjadi wadah pemenuhan verbal (membaca, menghitung, dan menulis).

\section{Input Evaluation}

Berdasarkan data dari Dinas Kota Palembang tahun 2016 terdiri dari 666 satuan 
PAUD dan yang terafiliasi dengan Puskesmas setempat terdiri dari 534 satuan PAUD berdasarkan data Dinas Kesehatan Kota Palembang tahun 2016, dengan jumlah terbanyak terletak di wilayah Kelurahan Sukajaya dan Lorok Pakjo yaitu masing-masing sebanyak 17 satuan PAUD. Kemudian terdapat 39 Puskesmas di Kota Palembang dan setiap satu satuan puskesmas menaungi rata-rata 13,59 (dibulatkan menjadi 14 satuan PAUD) pada setiap Kecamatan di Kota Palembang. Pada tiap-tiap Puskesmas terdapat rata-rata 1 ahli gizi pada satu satuan Puskesmas di Kota palembang dan ada 6 dari 39 Puskesmas yang tidak memiliki tenaga gizi di fasilitas kesehatan di Puskesmas Kota Palembang.

Dari hasil wawancara dengan Ibu Budi Wayatini, S.Km, Kepala Bagian Program Balita Puskesmas Kelurahan Nagaswidak Kecamatan SU II Kota Palembang, beliau mengemukakan bahwa perbandingan jumlah satuan PAUD berdasarkan jumlah Puskesmas tersebut sudah ideal, dan jumlah tenaga ahli gizi pada tiap-tiap Puskesmas tersebut sudah memenuhi standar yang ideal untuk melayani satuan PAUD di tiap tiap wilayahnya (Hasil Wawancara Pada Tanggal 12 Desember 2017). Kemudian wawancara dengan ibu Hj Eni Hardiani, S.KM., M.Si Kepala Bidang Kesehatan Masyarakat Dinas Kesehatan Kota Palembang yang menyatakan bahwa setiap satuan PAUD harus melapor keberadaannya ke Puskesmas terdekat untuk menjalin kerjasama dengan Puskesmas melalui MOU (Hasil Wawancara Tanggal 13 Desember 2017). Kemudian hasil wawancara dengan Ibu Erna Ningsih, SPd AUD Kepala sekolah TK Negeri Pembina 1 Palembang yang menyatakan bahwa TK Negeri Pembina I Palembang memiliki kerjasama dengan Puskesmas Kecamatan Padang Selasa. Kerjasama tersebut bersifat memorandum atau kesepakatan tertulis antara TK Negeri Pembina I Palembang dengan Puskesmas Kecamatan Padang Selasa (Hasil Wawancara Tanggal 9 Desember 2017).

Hasil wawancara di atas, mengemukakan bahwa satuan PAUD Kota Palembang telah mendapatkan akses layanan kesehatan dan gizi. Kemudian Kota Palembang juga memiliki sumber daya yang memadahi untuk memberikan akses layanan kesehatan dan gizi di satuan PAUD. Akan tetapi, perlu adanya koordinasi yang intensif antara satuan PAUD dan Puskesmas setempat agar pemenuhan layanan kesehatan tersebut dapat berjalan dengan baik. kerana ada beberapa satuan PAUD yang masih belum menjalin kerjasama dengan puskemas diwilayahnya karena kurangnya koordinasi dan informasi kepada satuan PAUD tersebut. Permasalahan inilah kemudian menyebabkan satuan PAUD tersebut belum mendapatkan 
layanan kesehatan dan gizi dari Puskesmas setempat.

Berdasarkan hasil wawancara dengan Ibu Budi Wayatini, S.Km, Kepala Bagian Program Balita Puskesmas Kelurahan Nagaswidak Kecamatan SU II Kota Palembang yang menyatakan bahwa kendala yang dihadapi dilapangan adalah kurangnya koordinasi dalam melaksanakan pelayanan kesehatan di satuan PAUD. Satuan PAUD terkesan kurang merespon kegiatan kesehatan anak usia dini yang diselenggarakan oleh Puskesmas pada jadwal yang telah ditentukan. Satuan PAUD masih mengaggap bahwa layanan kesehatan tersebut adalah kegiatan yang menjadi program Puskesmas, padahal kegiatan ini adalah program bersama antara satuan PAUD dan Dinas Kesehatan yang melalui Puskesmas (Hasil Wawancara Pada Tanggal 12 Desember 2017). Kemudian, hasil wawancara dengan ibu Desi Andriani, M.Pd Dosen PG PAUD Universitas PGRI Palembang yang menyatakan bahwa sarana prasarana serta sumberdaya sesungguhnya tidak menjadi kendala dalam penyelenggaraan program dikarenakan penyelengaraan program Pengembangan Anak Usia Dini Holistik Integratif di satuan PAUD hanyalah masalah koordinasi antara tiap tiap sektor yang terkait. Untuk sarana kegiatan penyelengaraan program seperti kegiatan parenting, penyuluhan kesehatan, dan lain sebagainya dapat memakai aula atau ruang kelas pada tiap tiap satuan PAUD. Dengan demikian, apabila satuan PAUD dapat menjalin koordinasi dengan baik pada setiap sektor terkait, maka penyelenggaraan Pengembangan Anak Usia Dini Holistik Integratif di satuan PAUD Kota Palembang akan terlaksana dengan baik (Hasil Wawancara Pada Tanggal 16 Desember 2017).

Dengan demikian, dapat dikemukakan bahwa keadaan satuan PAUD Kota Palembang saat ini tidak menjadi kendala yang berarti untuk menyelenggarakan program Pengembangan Anak Usia Dini Holistik Integratif. Untuk khususnya untuk penyelenggaraan layanan kesehatan dan gizi, satuan PAUD tidak membutuhkan sarana prasarana yang sulit untuk dipersiapkan. Satuan PAUD hanya perlu menyediakan aula atau tempat yang bisa digunakan untuk melaksanakan kegiatan-kegiatan yang berkaitan dengan layanan kesehatan dan gizi.

Pada aspek pengasuhan dan keamanan belum berjalan sesuai dengan konsep penyelenggaraan yang diatur dalam Perpres No 60 tahun 2013. Belum ada kooordinasi antara kepolisian dan satuan PAUD menyebabkan layanan pengasuhan dan keamanan belum berjalan. Hal ini berdasarkan hasil wawancara dengan Bapak Aiptu Irwan Kurniawan, Staff Adminsitrasi Umum Polsek Kertapati Palembang yang menyatakan bahwa sejauh ini belum 
ada kegiatan sosialisasi ke satuan PAUD yang dilaksanakan oleh Polsek di Kota Palembang. mengenai narasumber, Kepolisian memiliki sumberdaya Kepolisian di Kota Palembang sangat mencukupi untuk penyelenggaraan sosialisasi keamanan dan perlindungan pada satuan PAUD Kota Palembang. Akan tetapi, tidak adanya koordinasi antara satuan PAUD Kota Palembang dan Kepolisian Kota Palembang menyebabkan tidak terlaksananya kegiatan tersebut di satuan PAUD Kota Palembang. Namun demikian, Polres dan Polsek, Khususnya Polsek Kertapati Palembang akan siap membantu bila diperlukan untuk menjadi narasumber kegiatan sosialisasi terkait keamanan dan perlindungan anak usia dini di satuan PAUD Kota Palembang (Hasil Wawancara Pada Tanggal 20 Desember 2017).

Karena hanya layanan kesehatan melalui koordinasi antara Puskesmas dan satuan PAUD Kota Palembang yang sudah berjalan dan layanan lain belum berjalan maka peneliti belum menemukan bidang bidang terkait penyelenggaraan Pengembangan Anak Usia Dini di satuan PAUD pada instansi isntansi lain. Oleh karena itu, hanya sumber daya kesehatan yang dapat dijelaskan dalam penelitian ini meskipun untuk sumber daya yang lain seperti sumber daya keamanan dan pengasuhan juga dinilai memadahi dalam perspektif asumsi peneliti dari kondisi Kota Palembang saat ini.

\section{Process Evaluation}

Dari hasil evaluasi process program Pengembangan Anak Usia Dini Holistik Integratif di satuan PAUD Kota Palembang, maka dapat dikemukakan bahwa koordinasi dengan instansi terkait pelayanan Pengembangan Anak Usia Dini Holistik Integratif termasuk dalam kategori baik. Dari angket yang ditebar oleh peneliti dari 53 responden terdapat 15 responden atau 28\% dengan kategori rendah, 5 responden atau 9.4\% dengan kategori sedang, 33 responden atau $62,2 \%$ dengan kategori baik. Akan tetapi, persepektif koordinasi, bimbingan dan pengawasan dari instansi terkait layanan Pengembangan Anak Usia Dini Holistik Integratif di satuan PAUD Kota Palembang menurut kepala sekolah satuan PAUD adalah Puskesmas dan Dinas Pendidikan. Artinya, instansi terkait tersebut diartikan oleh satuan PAUD hanyalah Dinas Pendidikan dan Puskesmas saja.

Kemudian pelayanan, supervisi, advokasi, serta evaluasi dan pelaporan terkait layanan pendidikan di satuan PAUD Kota Palembang masih dalam kategori rendah, atau belum berjalan dengan baik bila dilihat jumlah persentase responden dalam kategori rendah sangat tinggi. Dari 53 responden, terdapat 4 responden atau 7.5\% dengan kategori sedang, dan 49 
responden atau 92,5\% dengan kategori rendah. Hal ini dikarenakan belum terlihat keseriusan pemerintah khususnya Dinas Pendidikan Kota Palembang dalam melakukan bimbingan teknis, pelatihan serta evaluasi terkait penyelenggaraan program pendidikan di satuan PAUD Kota Palembang dengan optimal.

Kemudian pelayanan, supervisi, advokasi, serta evaluasi dan pelaporan terkait layanan kesehatan yang dilaksanakan oleh Puskesmas di satuan PAUD Kota Palembang termasuk dalam kategori tinggi, atau telah berjalan dengan baik. dari hasil analisis data kuantitatif deskriptif terdapat 28 responden atau $62.8 \%$ dengan kategori tinggi, dan terdapat 16 responden atau 30,2 \% dengan kategori sedang. Kemudian, terdapat 9 responden atau $17 \%$ dengan dengan kategori rendah. Hasil ini sesuai dengan data Dinas Kota Palembang Tahun 2017 yang menyatakan bahwa dari 666 jumlah satuan PAUD Kota Palembang, 534 satuan PAUD telah terafiliasi ke setiap satuan Puskesmas pada tiap-tiap kecamatan di Kota Palembang. Hal ini menandakan bahwa layanan kesehatan telah dijalankan oleh Dinas Kesehatan melalui Puskesmas setempat.

Selanjutnya layanan sosial meliputi bimbingan teknis, supervisi, advokasi, pelatihan, serta evaluasi dan pelaporan terkait layanan sosial yang terdiri dari perlindungan, rehabilitasi, dan penyuluhan kepada orang tua dalam kategori rendah, berdasarkan hasil analisis menjelaskan bahwa seluruh responden, atau 53 responden dalam kategori rendah. Tidak terlibatnya Dinas Sosial dalam kegiatan layanan PAUD Kota Palembang, menyatakan bahwa belum ada koordinasi yang baik antara satuan PAUD dengan Dinas Sosial Kota Palembang dalam upaya penyelenggaraan Pengembangan Anak Usia Dini Holistik Integratif di satuan PAUD Kota Palembang. Peran Dinas Pengendalian Penduduk dan Keluarga Berencana Kota Palembang terkait penyelenggaraan layanan Pengembangan Anak Usia Dini Holistik Integratif di satuan PAUD yang meliputi bimbingan teknis, supervisi, pelatihan, serta evaluasi dan pelaporan juga masih dalam kategori rendah, atau belum berjalan dengan baik. begitu juga dengan layanan Dinas Kependudukan dan Catatan Sipil Kota Palembang, yang mencakup pelayanan bimbingan teknis, supervisi, advokasi, serta penyuluhan tentang hak anak memiliki identitas akta kelahiran kepada orang tua masih dalam kategori sangat kurang.

Peran Kepolisian dalam hal ini Polres dan Polsek yang mencakup pelayanan, pelatihan, penyuluhan, bimbingan teknis, advokasi serta supervisi terkait layanan keamanan dan ketertiban di satuan PAUD, serta perlindungan hukum dari tindak penelantaran dan 
kekerasan terhadap anak di dalam keluarga di satuan PAUD Kota Palembang dalam kategori rendah. Kemudian peran serta tokoh masyarakat dalam pelaksanaan layanan Pengembangan Anak Usia Dini Holistik Integratif di satuan PAUD Kota Palembang dalam kategori rendah, atau belum adanya koordinasi dengan baik antara satuan PAUD Kota Palembang dengan tokoh masyarakat setempat guna meningkatkan penyelenggaraan layanan PAUD. Kemudian peran orang tua sebagai mitra termasuk dalam dalam kategori baik. Dari hasil analisis terdapat 12 responden atau $22.6 \%$ dalam kategori tinggi, dan 41 responden atau $77.4 \%$ dengan kategori sedang atau baik. Dengan demikian, dari seluruh unsur yang terkait dengan penyelenggaraan program Pengembangan Anak Usia Dini Holistik Integratif di satuan PAUD Kota Palembang, hanya layanan kesehatan dan gizi serta peran orang tua yang sudah berjalan dengan baik.

\section{Product Evaluation}

Hasil wawancara yang di lakukan oleh peneliti dengan Ibu Tuti Susanti, S.Km, kepala bagian balita di Puskesmas Kecamatan 10 Ulu Palembang, beliau mengemukakan bahwa layanan aspek kesehatan yang diberikan oleh Puskemas di satuan PAUD Kota Palembang sangat membantu orang tua untuk mengetahui bagaimana seharusnya orang tua memberikan makanan yang bergizi bagi anak, dan batasan-batasannya. Selain untuk pemenuhan gizi anak juga pengetahuan tersebut dapat mencegah obesitas bagi anak (Hasil Wawancara Pada Tanggal 26 Desember 2017). Hasil wawancara tersebut sesuai dengan hasil wawancara yang diberikan oleh peneliti yang ditujukan kepada 76 orang tua sebagai responden pada tanggal 16 September 2017. Peneliti menemukakan bahwa terdapat $57,89 \%$ orang tua menyatakan anak mereka mendapatkan layanan kesehatan selain layanan pendidikan dan 26,31\% hanya mendapatkan layanan pendidikan kemudian 15,79\% mendapatkan layanan pengasuhan. Adapun hasil wawancara tersebut dapat dilihat pada diagram berikut ini.

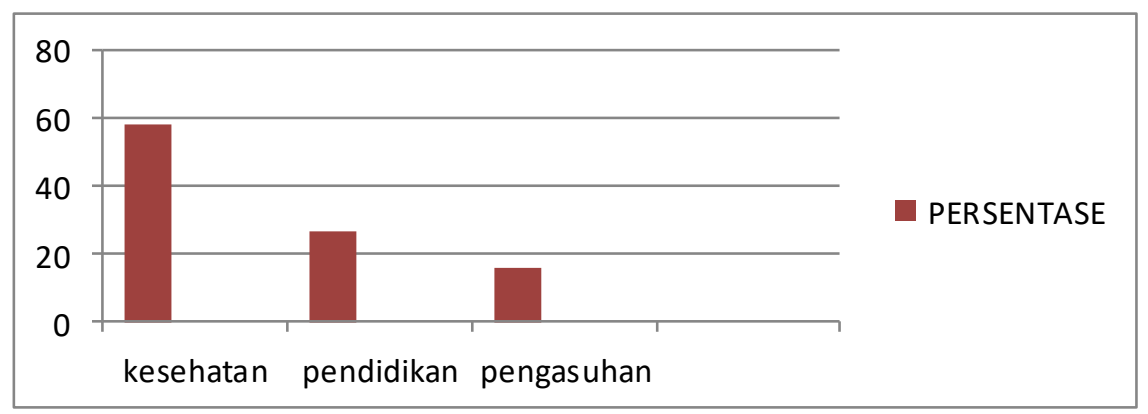

Gambar 3. Diagram Persepsi Orang Tua Terhadap Layanan PAUD Kota Palembang 
Dari hasil wawancara di atas, dapat dikemukakan bahwa dampak dari pelayanan kesehatan yang dilaksanakan di satuan PAUD Kota Palembang saat ini masih pada batas edukasi terhadap orang tua tentang kesehatan anak. Layanan tersebut saat ini sedang berupaya untuk menanamkan pengetahuan kepada orang tua anak akan pentingnya pemenuhan aspek kesehatan dan gizi anak. Tidak hanya kepada masyarakat ekonomi menengah kebawah saja, akan tetapi kepada setiap lapisan masyarakat. Khususnya untuk beberapa satuan PAUD di Kota Palembang, yang menganggap bahwa layanan kesehatan dan gizi, di nilai tidak terlalu penting dilaksanakan di satuan PAUD. Hal ini di karenakan oleh beberapa alasan antara lain karena mayoritas orang tua anak yang bersekolah di satuan PAUD tersebut termasuk dalam kategori ekonomi menengah ke atas dan anak anak mereka sudah sehat dan selalu mendapatkan asupan gizi di rumah.

Dampak lain dari edukasi yang dilaksanakan oleh Puskesmas di satuan PAUD adalah kesadaran terhadap pentingnya untuk bersama-sama dalam upaya mendidik anak. Dari hasil analisa peneliti, peneliti menemukan hubungan kemitraan antara satuan PAUD dengan orang tua anak dalam memantau pertumbuhan dan perkembangan anak. Kemitraan yang terjalin antara orang tua dan satuan PAUD tersebut dapat menjadi pondasi yang kuat bagi satuan PAUD untuk melaksanakan pelayanan dengan maksimal. Layanan yang maksimal tersebut tentu mengacu pada tujuan layanan Pengembangan Anak Usia Dini Holistik integratif yaitu kesiapan anak usia dini baik kesiapan mental, spiritual, sosial serta intelektual dalam melaksanakan kegiatan pendidikan yang akan di tempuhnya kelak, serta dapat menjadi generasi penerus bangsa yang dapat bersaing di era global.

Dengan demikian, maka dapat dikemukakan oleh peneliti bahwa penyelenggaraan program Pengembangan Anak Usia Dini Holistik Integratif di satuan PAUD Kota Palembang belum berjalan sesuai dengan teknis penyelenggaraannya. Dengan demikian, dampak (impact) belum dapat diukur dan diprediksi oleh peneliti melalui program yang sebagian besar aspeknya tidak berjalan dan tidak memenuhi kriteria holistik integratif. Akan tetapi, layanan kesehatan yang dilaksanakan oleh Puskesmas pada satuan PAUD Kota Palembang sudah memberikan manfaat bagi anak usia dini. Selain itu, kerjasama antara PAUD dan Puskesmas melalui $M O U$ dapat menjadi modal yang baik bagi penyelenggaraan layanan Pengembangan Anak Usia Dini Holistik Integratif di satuan PAUD Kota Palembang ke depannya.

Dari hasil evaluasi context program Pengembangan Anak Usia Dini Holistik Integratif 
di satuan PAUD Kota Palembang, dapat dikemukakan bahwa program Pengembangan Anak Usia Dini Holistik Integratif memiliki dasar hukum yang kuat, akan tetapi penyelenggaraan program Pengembangan Anak Usia Dini Holistik Integrtaif di satuan PAUD Kota Palembang belum memiliki landasan hukum yang kuat. Oleh karenanya, untuk menyelenggarakan program Pengembangan Anak Usia Dini Holsitik Integratif di satuan PAUD, Pemerintah Daerah harus memiliki mekanisme penyelenggaraan sesuai dengan kekhasan daerahnya masing-masing dan tetap berpedoman pada norma, standar, prosedur yang telah ditetapkan oleh Kementrian/Lembaga pemerintah nonkementerian terkait serta berkoordinasi dengan gugus tugas. Sebagaimana bunyi pasal 17 ayat 6 yang menyatakan bahwa gugus tugas Provinsi, Kabupaten/Kota dalam melaksanakan Pengembangan Anak Usia Dini Holistik Integratif berpedoman pada norma, standar, prosedur dan kriteria yang ditetapkan oleh kementerian/lembaga pemerintah nonkementerian terkait serta berkoordinasi dengan Gugus Tugas. Serta pasal 16 ayat 1 yang berbunyi Pemerintah Daerah melaksanakan Pengembangan Anak Usia Dini Holistik Integratif di daerah masing masing dengan mengacu kepada kebijakan yang ditetapkan oleh Gugus Tugas. Kemudian pasal 12 ayat 2 yang berbunyi anggota Sub Gugus Tugas sebagaimana dimaksud pada ayat (1) terdiri atas Pejabat Kementerian/Lembaga terkait.

Kemudian rumusan penyelenggaraan program juga mengacu pada Permen No 58 Tahun 2009 yang mengatur tentang standar Pendidikan Anak Usia Dini dimana Permen ini sudah merefleksikan program Pengembangan Anak Usia Dini Holistik Integratif serta mengacu juga pada Direktorat Pembinaan Anak Usia Dini sebagai subgusus tugas yang telah menerbitkan petunjuk teknis penyelenggaraan Pengembangan Anak Usia Dini Holistik Integratif di satuan PAUD pada tahun 2015. Selain itu, untuk menyelenggarakan Pengembangan Anak Usia Dini Holistik Integratif dengan maksimal idealnya dilaksanakan di dalam satu lembaga, dan lembaga yang siap dan mampu untuk mengakomodir pemenuhan seluruh aspek kebutuhan anak usia dini adalah satuan PAUD. Hal ini kemudian menjadi lebih penting lagi, apabila melihat espektasi sebagian besar masyarakat kepada satuan PAUD masih sebagai wadah untuk memenuhi kemampuan verbal saja. Dengan menyelenggarakan Pengembangan Anak Usia Dini Holistik Integratif di satuan PAUD kota Palembang, satuan PAUD dapat mengedukasi masyarakat khususnya edukasi tentang pentingnya pemenuhan setiap esensi kebutuhan anak, dan diharapkan bahwa PAUD tidak lagi menjadi wadah 
pemenuhan kebutuhan verbal melainkan lembaga yang dapat memberikan layanan yang holistik dan terintegrasi dalam upaya memenuhi kebutuhan anak usia dini.

Dari hasil evaluasi input program Pengembangan Anak Usia Dini Holistik Integratif di satuan PAUD Kota Palembang, maka dapat dikemukakan bahwa Pemerintah Kota Palembang memiliki sumberdaya yang memadahi untuk menyelenggarakan program Pengembangan Anak Usia Dini Holistik Integratif di satuan PAUD khususnya pada aspek kesehatan dan gizi, dan aspek perlindungan dan keamanan. Akan tetapi, penyelenggaraan program di satuan PAUD Kota Palembang belum berjalan sesuai dengan apa yang di rumuskan di dalam Perpres No 60 Tahun 2013 serta petunjuk teknis penyelenggaraan layanan Pengembangan Anak Usia Dini Holistik Integratif di satuan PAUD tahun 2015. Kecuali, layanan kesehatan dan gizi yang sudah dilaksanakan oleh Puskesmas dengan beberapa catatan bahwa mekainisme pelaksanaan harus di perbaiki oleh kedua lembaga. Khususnya masalah koordinasi yang belum berjalan dengan baik. Permasalahan ini sangat di pengaruhi oleh pemahaman kedua lembaga (puskesmas dan satuan PAUD) terhadap kewajiban pelaksanaan Pengembangan Anak Usia Dini Holistik Integratif. Oleh karena itu, perlu adanya sosialisasi dari Pemerintah Daerah mengenai program Pengembangan Anak Usia Dini Holistik Integratif ke setiap lembaga yang terkait dengan pelaksanaan program.

Permasalahan yang kedua adalah belum ada garis komunikasi yang jelas antar instansi terkait penyelenggaraan Pengembangan Anak Usia Dini Holistik Integratif menyebabkan penyelenggaraan layanan tidak berjalan dengan maksimal. Oleh karena itu, peneliti menilai bahwa Pemerintah Daerah memiliki peran besar dalam membentuk garis komunikasi tersebut. Garis komunikasi harus di rumuskan melalui Peraturan Daerah (Perda) yang dapat mengikat dan di rancang dengan baik menyangkut setiap aspek pelayanan kebutuhan anak usia dini di satuan PAUD Kota Palembang.

Penyelenggaraan layanan Pengembangan Anak Usia Dini Holistik Integratif juga harus di rencanakan dengan matang melalui penyusunan program kerja penyelenggaraan Pengembangan Anak Usia Dini Holistik Integratif disatuan PAUD. Penyusunan program kerja tersebut dapat melibatkan tim ahli yang berasal dari masyarakat, akademisi, dan praktisi PAUD Kota Palembang. Kemudian rencana kerja program tersebut dilaporkan kepada seluruh instansi terkait untuk di pelajari dan di tindaklanjuti. Hal ini sesuai dengan Perpres No 60 Tahun 2013 pasal (7) Pasal 16 Ayat 2 menyatakan bahwa dalam melaksanakan 
Pengembangan Anak Usia Dini Holisitik-Integratif, Pemerintah Daerah dapat bekerja sama dengan Pemerintah, perguruan tinggi, organisasi profesi, organisasi kemasyarakatan, organisasi keagamaan, lembaga swadaya masyarakat, dunia usaha, dan anggota masyarakat.

Dari hasil evaluasi process, peneliti menemukan bahwa hanya layanan kesehatan yang diselenggarakan oleh Puskesmas yang telah berjalan dengan cukup baik. Dengan demikian, satuan PAUD harus meningkatkan koordinasi pada tiap-tiap instansi khususnya dengan Puskesmas Kota Palembang dan instansi instansi lain yang terkait pada umumnya. Koordinasi tersebut dapat dilaksanakan apabila satuan PAUD telah menyusun program penyelenggaraan Pengembangan Anak Usia Dini Holistik Integratif di tiap tiap satuan PAUD. Kemudian program tersebut dilaporkan kepada seluruh instansi terkait penyelenggaraan Pengembangan Anak Usia Dini Holistik Integratif, khususnnya instansi instansi yang masih belum terlibat dalam penyelenggaraan Pengembangan Anak Usia Dini Holistik Integratif di satuan PAUD Kota Palembang. Untuk menyusun program tersebut agar dapat dirancang dengan baik, dengan melibatkan tim ahli yang berasal dari masyarakat, akademisi, dan pratisi praktisi PAUD Kota Palembang.

Tidak hanya di dalam perencanaan dan pelaksanaan saja diperlukan koordinasi, akan tetapi dalam proses evaluasi penyelenggaraan Pengembangan Anak Usia Dini Holistik Integratif di Satuan PAUD perlu dilakukan koordinasi dengan baik, agar satuan PAUD dapat memperoleh data yang akurat berupa hasil instrumen pemantauan yang menggambarkan hasil penyelenggaraan Pengembangan Anak Usia Dini Holistik Integratif oleh setiap sektor terkait. Hasil evaluasi tersebut dapat dijadikan laporan oleh satuan PAUD kepada Dinas Pendidikan Kota Palembang untuk di tindaklanjuti pada tahapan tahapan selanjutnya.

Kemudian, dalam penyelenggaraan layanan Pengembangan Anak Usia Dini Holistik Integratif di satuan PAUD Kota Palembang, harus ada mekanisme penyelenggaraan yang sistematis dan terintegrasi dengan baik antara tiap tiap sektor terkait dengan penyelenggaraan program Pengembangan Anak Usia Dini Holistik Integratif di satuan PAUD Kota Palembang. Mekanisme koordinasi tersebut akan lebih efektif lagi apabila kedepannya dapat diatur di dalam peraturan daerah yang mengikat dan menjelaskan garis komunikasi antara tiap tiap instansi terkait. Melalui hasil evaluasi yang di lakukan oleh peneliti, peneliti dapat menawarkan flowcharts mekanisme penyelenggaraan yang ditawarkan di dalam penelitian ini adalah sebagai berikut 


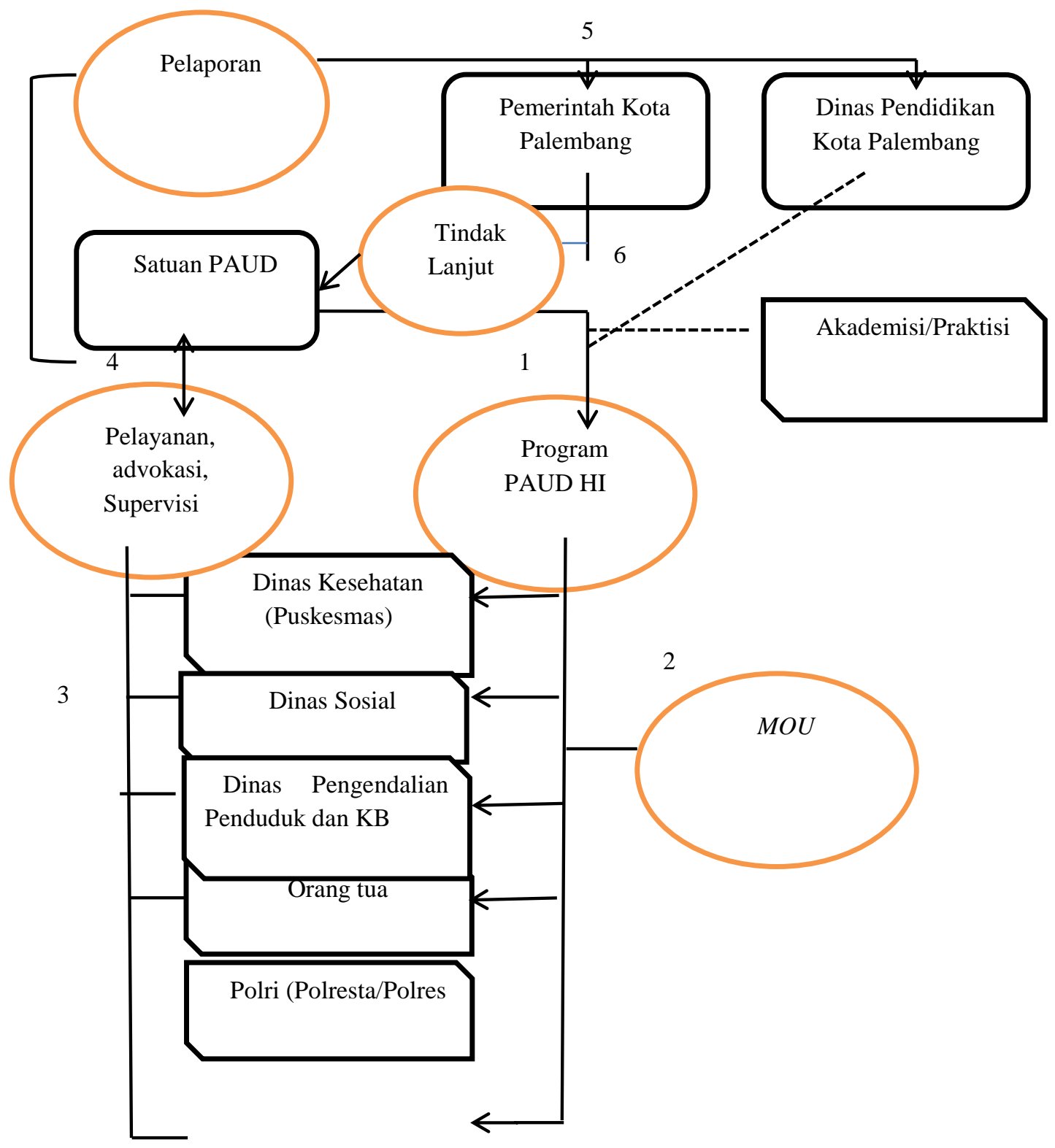

\section{Gambar 4. Flowcharts Perencanaan program Pengembangan Anak Usia Dini Holistik Integratif Di Satuan PAUD}

Dari flowchart di atas, yang di tekankan oleh peneliti adalah konsep penyusunan rancangan mekanisme penyelenggaraan pengembangan anak usia dini holistik integratif di satuan PAUD Kota Palembang dengan melibatkan Dinas Pendidikan dalam hal ini adalah Bidang Pendidikan Anak Usia Dini dan Masyarakat, serta Seksi Kurikulum PAUD dan Pendidikan Masyarakat, praktisi PAUD serta akademisi yang dapat memberikan masukan bagaimana rancangan program Pengembangan Anak Usia Dini Holistik Integratif yang seharusnya dilaksanakan di satuan PAUD Kota Palembang, mulai dari susunan kegiatan 
sampai evaluasi pelaksanaan Pengembangan Anak Usia Dini Holistik Integratif di satuan PAUD. Hal ini sesuai dengan Perpres No 60 Tahun 2013 Pasal 16 bahwa dalam melaksanakan Pengembangan Anak Usia Dini Holisitik Integratif sebagaimana dimaksud pada ayat (1) Pemerintah Daerah dapat bekerja sama dengan Pemerintah, perguruan tinggi, organisasi profesi, organisasi kemasyarakatan, organisasi keagamaan, lembaga swadaya masyarakat, dunia usaha, dan anggota masyarakat.

Kemudian, pelaksanaan program dengan desain yang sudah dirancang harus didokumentasikan dengan baik pada setiap unsur holistik integratif, dan rancangan program Pengembangan Anak Usia Dini Holistik Integratif yang akan dilaksanakan, sudah disusun mulai awal tahun, kemudian di sosialisasikan kepada pendidik serta orang tua anak agar program tersebut dapat dipahami oleh pendidik dan orang tua anak. Dengan memiliki rancangan program Pengembangan Anak Usia Dini Holistik Integratif di satuan PAUD yang telah disusun dengan sistematis, maka program tersebut akan dapat laksanakan dengan maksimal, baik itu di dalam satuan PAUD maupun pada tiap tiap instansi terkait penyelenggaraan Pengembangan Anak Usia Dini Holistik Integratif di Kota Palembang.

Untuk memperkuat pondasi penyelenggaraan layanan Pengembangan Anak Usia Dini Holistik Integratif di satuan PAUD, Pemerintah Kota melalui instansi terkait harus dapat mensosialisasikan layanan Pengembangan Anak Usia Dini Holistik Integratif kepada masyarakat, hal ini bertujuan agar pemerintah dapat mengedukasi masyarakat tentang pentingnya pemenuhan setiap esensi kebutuhan anak. Dengan demikian, satuan PAUD tidak lagi menjadi lembaga yang di tuntut untuk memenuhi kebutuhan verbal seperti yang diespeksikan oleh masyarakat. Akan tetapi, satuan PAUD dapat menjadi lembaga yang holistik dan terintegrasi dalam upaya memenuhi seluruh aspek kebutuhan anak usia dini.

Dari hasil evaluasi product program Pengembangan Anak Usia Dini Holistik Integratif di satuan PAUD Kota Palembang, dapat dikemukakan bahwa penyelenggaraan program Pengembangan Anak Usia Dini Holistik Integratif di satuan PAUD Kota Palembang belum berjalan sesuai dengan teknis penyelenggaraannya. Dengan demikian, dampak (impact) belum dapat diukur dan diprediksi oleh peneliti melalui program yang sebagian besar aspeknya tidak berjalan dan tidak memenuhi kriteria holistik integratif. Akan tetapi, layanan kesehatan yang dilaksanakan oleh Puskesmas pada satuan PAUD Kota Palembang sudah memberikan manfaat bagi anak usia dini. Selain itu, kerjasama antara PAUD dan Puskesmas melalui $M O U$ 
dapat menjadi modal yang baik bagi penyelenggaraan layanan Pengembangan Anak Usia Dini Holistik Integratif d satuan PAUD Kota Palembang ke depannya. Dari hasil evaluasi ini maka peneliti merekomendasikan agar ada revisi terhadap penyelenggaraan program yang mengacu pada 1) Perda Kota Palembang; 2) Perpres No 60 Tahun 2013, dan 3) Permen No 59 Tahun 2009.

Hasil penelitian dan pembahasan yang dikemukakan di atas, di dukung oleh beberapa penelitian terdahulu yaitu penelitian yang dilakukan oleh Slot,P L,. Leseman, P, P.M Verhagen, J, Mulder, H (2015) dengan hasil penelitian yang mengemukakan bahwa indicate that group size and child to teacher ratio are not related to emotional and educational process quality in the Dutch ECEC system. Teachers' formal preservice education has a positive, but small association with emotional process quality. The use of an education program and professional development activities at the center showthe strongest associations with emotional and educational process quality. Kemudian Clements, Douglas, Fuson, Karen \& Sarama. (2017) dengan hasil penelitian yang mengemukakan bahwa ada 4 kritik terhadap kebijakan pendidikan anak di United State melalui Common Core State Standards Mathematics (CCSSM) yaitu 1) no one who helped develop the standards had any expertise in the education of young children; 2) the CCSSM dictates scripted curricula and didactic instruction rigidly applied to all children at the same pace; 3) the standards emphasize academic skills and leave no time for play, exploratory approaches, or socialemotional development; 4) the standards are too early and therefore developmentally inappropriate for children in the early grades.

Rao Nirmala, Pearson Veronica (2009) dengan hasil penelitian yang mengemukakan bahwa EFA policies at the central level unequivocally support the need for ECCE as a means to improve the health, wellbeing and school readiness of childrenbelow six years. These policies are framed to beinclusive of all disadvantaged children, particularly those in extreme poverty, girls, children with adisability and those from ethnic minorities. At themoment, Cambodian children have some of the worsthealth indices in the East Asia and Pacific region, including stunting and severe malnutrition as well ashigh mortality rates. The government accepts thatchildren who are underfed and understimulated areunlikely to make the transition to Grade 1 in primary school successfully. This accounts for the very highlevels of drop-outs and grade repetitions that arecommon in Cambodia. On average it takes 10.8 years for a 
child to complete six years of primary school.

Dari beberapa penelitian di atas, jelas bahwa kebijakan yang dikeluarkan oleh pemerintah memiliki peran yang sangat dominan dalam penyelenggaraan pendidikan khususnya di satuan PAUD. Peran pemerintah melalui kebijakan penyelenggaraan pendidikan menjadi variabel penentu dibandingkan variabel variabel yang lain. Kebijakan tersebut dapat menjadi acuan formal bagi penyelenggara layanan PAUD agar dapat memberikan layanan sesuai dengan kebutuhan anak, keseimbangan antara pemenuhan verbal dan bermain anak, serta proses pencapaian tujuan jangka panjang layanan PAUD.

Penelitian yang dilakukan oleh Handayani, Munawar, Chandra, Prasetiyawati (2011) yang menyimpulkan bahwa pelatihan program PAUD holistik integratif dapat meningkatkan kualitas Pos PAUD. Fatmawati (2011) mendukung penelitian ini dengan hasil penelitian yang mengemukakan bahwa setiap anak tanpa terkecuali harus terpenuhi hak haknya. Hak untuk mempertahankan hidup, hak untuk tumbuhkembang serta memperoleh perlindungan agar terhindar dari diskriminasi dan eksploitasi. Salah satu langkah untuk mewujudkannya adalah dengan cara melakukan pengasuhan, pembinaan, pendampingan, perawatan, pendidikan dan perlindungan bagi anak.

Kiam (2014) dengan hasil penelitian menjelaskan bahwa proses implementasi kebijakan program pendidikan non formal pada PAUD di Kecamatan Sintang belum berjalan dengan baik, hal ini dikarenakan rendahnya dukungan pemerintah dalam penyelenggaraan pendidikan anak usia dini, yayasan atau organisasi, masih belum sinergis antara pemerintah, pengelola lembaga PAUD dan masyarakat untuk melakukan pengawasan dan kontrol secara bersama. Pembangunan PAUD melibatkan pemerintah, swasta dan masyarakat. Agar komunikasi berjalan lancar maka seharusnya ada instansi koordinator seluruh pembangunan PAUD. Supaya proses implementasi kebijakan pendidikan PAUD non formal berjalan lancar, maka masyarakat diharapkan juga terlibat dalam kontrol/pengawasan, penilaian serta dalam pengambilan keputusan terhadap pelaksanaan kebijakan PAUD. Penelitian yang dilakukan oleh Anamara (2014) dengan hasil penelitian menyimpulkan bahwa alat permainan luar ruang beralaskan lantai belum memperhatikan faktor keselamatan anak.

Penelitian yang dilakukan oleh Diadha (2015) dengan hasil penelitian yang mengemukakan bahwa keterlibatan orang tua dalam pendidikan anak dapat diwujudkan dalam berbagai bentuk aktifitas yang dilakukan oleh orang tua melalui kerjasama dengan guru baik 
di rumah atau di sekolah, guna memaksimalkan perkembangan dan pendidikan anak di sekolah demi keuntungan mereka, anak dan program sekolah. Hal tersebut sangat penting bagi kesinambungan antara pendidikan di rumah dan di sekolah. Pelaksanaan keterlibatan orang tua sendiri sangat memerlukan kesadaran dan upaya dari orang tua terlebih lagi pihak sekolah, karena orang tua akan terlibat dengan aktif apabila sekolah berusaha untuk memberikan rasa nyaman bagi orang tua. Penelitian yang di lakukan oleh Hartanti (2012) dengan hasil penelitian yang mengemukakan bahwa berdasarkan empat faktor yang berpengaruh dalam implementasi kebijakan, faktor komunikasi dan disposisi merupakan faktor yang lebih dominan mempengaruhi keberhasilan program, yang dibuktikan bahwa para pihak yang terlibat berupaya melakukan pendekatan dengan cara menyampaian informasi langsung kepada semua pihak yang terlibat secara jelas selama program berlangsung. Hal ini membuktikan bahwa kedua faktor tersebut lebih dominan dan mampu mempengaruhi terciptanya keberhasilan implementasi program PAUD.

\section{SIMPULAN}

Dari hasil penelitian dan pembahasan di atas, maka peneliti dapat menarik kesimpulan bahwa penyelenggaraan program Pengembangan Anak Usia Dini Holistik Integratif memiliki landasan hukum yang kuat, akan tetapi penyelenggaran program Pengembangan Anak Usia Dini Holistik Integratif di satuan PAUD Kota Palembang masih belum memiliki landasan hukum yang kuat. Kemudian penyelenggaraan layanan Pengembangan Anak Usia Dini Holistik Integratif merupakan solusi yang cukup responsif terhadap kebutuhan PAUD .dalam upaya menjawab tuntutan masyarakat. Kemudian Kota Palembang memiliki sumber daya yang memadahi untuk menyelenggarakan layanan Pengembangan Anak Usia Dini Holistik Integratif. Hanya saja, penyelenggaraan layanan Pengembangan Anak Usia Dini Holistik Integratif di satuan PAUD Kota Palembang belum di rencanakan dengan baik. Belum ada rancangan program Pengembangan Anak Usia Dini Holistik Integratif yang jelas mulai dari susunan kegiatan hingga evaluasi pelaksanaan Pengembangan Anak Usia Dini Holistik Integratif di satuan PAUD. Dengan demikian harus ada perencanaan yang jelas mengenai penyelenggaraan layanan Pengembangan Anak Usia Dini Holistik Integratif di satuan PAUD. Untuk mendapatkan hasil yang maksimal perencanaan tersebut harus melibatkan Dinas Pendidikan, praktisi serta akademisi pendidikan, khususnya pendidikan PAUD.

Proses pelaksanaan layanan Pengembangan Anak Usia Dini Holistik Integratif di 
satuan PAUD Kota Palembang belum berjalan sesuai dengan teknis penyelenggaraan layanan Pengembangan Anak Usia Dini Holistik Integratif di satuan PAUD. Dari seluruh aspek terkait pelaksanaan layanan Pengembangan Anak Usia Dini Holistik Integratif, hanya Dinas Kesehatan melalui Puskesmas yang telah menjalankan fungsi sektoralnya. Dengan demikian, harus ada tindakan yang serius dari pemerintah Kota Palembang agar penyelenggaraan layanan Pengembangan Anak Usia Dini Holistik Integratif di satuan PAUD Kota Palembang dapat berjalan dengan maksimal.

Karena program Pengembangan Anak Usia Dini Holistik Integratif di satuan PAUD Kota Palembang belum terlaksana sesuai dengan petunjuk pelaksanaan layanan Pengembangan Anak Usia Dini Holistik Integratif di satuan PAUD. Artinya, belum ada dampak (impact) yang dapat diukur dan diprediksi melalui program yang sebagian besar aspeknya tidak berjalan dengan baik. Akan tetapi ada aspek yang telah berjalan dengan cukup baik yaitu layanan kesehatan yang dilaksanakan oleh Puskesmas pada satuan PAUD Kota Palembang. Kerjasama ini dapat menjadi modal yang baik untuk penyelenggaraan layanan Pengembangan Anak Usia Dini Holistik Integratif d satuan PAUD Kota Palembang, khususnya untuk mengedukasi masyarakat bahwa layanan kesehatan merupakan bagian penting dalam proses pendidikan anak usia dini. Adapun rekomendasi peneliti dari hasil evaluasi adalah agar pemerintah Kota Palembang merevisi penyelenggaraan program yang mengacu pada 1) Perda Kota Palembang; 2) Perpres No 60 Tahun 2013, dan 3) Permen No 59 Tahun 2009.

Dari pembahasan di atas, maka dapat dikemukakan beberapa saran, sebagai berikut.

1. Pemerintah Kota Palembang diharapkan dapat merumuskan aturan yang jelas antara instansi yang terkait penyelenggaraan layanan Pengembangan Anak Usia Dini Holistik Integratif khususnya di satuan PAUD Kota Palembang. Aturan yang mengatur garis komunikasi yang jelas tersebut dapat diatur dalam peraturan daerah yang mengacu pada Perpres No 60 Tahun 2013 dalam pengelolaan dan penyelenggaraan layanan Pengembangan Anak Usia Dini Holistik Integratif di satuan PAUD Kota Palembang. Dengan adanya PERDA Kota Palembang dan PERDA tersebut di sosialisasikan kepada seluruh isntansi terkait, maka penyelenggaraan layanan Pengembangan Anak Usia Dini Holistik Integratif akan dapat dilaksanakan dengan maksimal.

2. Pemerintah Kota Palembang diharapkan dapat menempatkan sumberdaya yang kompeten 
pada tiap tiap instansi terkait penyelenggaraan layanan Pengembangan Anak Usia Dini Holistik Integratif, khususnya pada struktur organisasi vital yang sangat berpengaruh terhadap penyelenggaraan layanan Pengembangan Anak Usia Dini Holistik Integratif di satuan PAUD Kota Palembang seperti tim evaluasi dan supervisi layanan program.

3. Pentingnya pemenuhan seluruh aspek kebutuhan anak usia dini harus di sosialisaikan kepada orang tua melalui instansi-instansi yang memiliki kewajiban serta tanggungjawab untuk menyelenggarakan layanan Pengembangan Anak Usia Dini Holistik Integratif. Sosialisasi tersebut juga bertujuan agar orang tua dapat menjadi mitra satuan PAUD untuk menyelenggarakan layanan Pengembangan Anak Usia Dini Holistik Integratif di satuan PAUD Kota Palembang. Selain itu, orang tua dapat memahami bahwa satuan PAUD bukan hanya sebagai wadah untuk mengasah kemampuan verbal anak usia dini.

4. Dinas Pendidikan Kota Palembang harus memperketat perizinan pendirian PAUD di Kota Palembang sesuai dengan ketentuan yang berlaku. Hal ini bertujuan untuk mencegah berdirinya satuan PAUD yang tidak dikelola dengan baik dan tidak memiliki fasilitas serta sumber daya yang memenuhi untuk penyelengaraan layanan PAUD di Kota Palembang. karena selama ini, pemerintah Kota Palembang masih mendahulukan kuantitas satuan PAUD dengan mendorong masyarakat untuk ikut ambil bagian dalam penyelenggaraan layanan PAUD. Pemerintah Kota Palembang harus mendorong masyarakat untuk ambil bagian dalam mensukseskan penyelenggaraan layanan Pengembangan Anak Usia Dini Holistik Integratif di satuan PAUD Kota Palembang. Dorongan kepada masyarakat dapat berupa membina lembaga swadaya masyarakat yang konsen terhadap penyelenggaraan layanan Pengembangan Anak Usia Dini Holistik Integratif di Kota Palembang umumnya. Karena salah satu sektor yang dapat menunjang suksesnya penyelenggaraan layanan Pengembangan Anak Usia Dini Holistik Integratif di satuan PAUD Kota Palembang adalah lembaga swadaya masyarakat melalui intervensinya.

5. Praktisi pendidikan khususnya praktisi Pendidikan Anak Usia Dini, harus ikut ambil bagian dalam mensukseskan penyelenggaraan layanan Pengembangan Anak Usia Dini Holistik Integratif di satuan PAUD Kota Palembang, dengan memberikan masukan yang membangun kualitas forum-forum PAUD seperti HIMPAUDI yang selama ini masih belum memiliki kegiatan yang berdampak bagi suksesnya penyelenggaraan layanan Pengembangan Anak Usia Dini Holistik Integratif di satuan PAUD Kota Palembang. 
6. Satuan PAUD harus aktif menjemput bola. Satuan PAUD diharapkan dapat menjadi penghubung antara tiap tiap instansi dalam upaya memaksimalkan penyelenggaraan layanan Pengembangan Anak Usia Dini Holistik Integratif di satuan PAUD.

7. Pendidik, pengelola, perangkat yang terkait dengan penyelenggaraan Pengembangan Anak Usia Dini Holistik Integratif harus memahami betul Perpres No 60 Tahun 2013, Permen No 58 Tahun 2006, serta Petunjuk teknis Penyelenggaraan Pengembangan Anak Usia Dini Holistik Integratif di satuan PAUD yang di keluarkan oleh Direktorat Pembinaan Anak Usia Dini Tahun 2015.

8. Harus ada satuan PAUD yang menjadi PAUD percontohan, di mana tata kelola satuan PAUD tersebut di rancang sesuai dengan Permen No 58 Tahun 2009 dan Juknis Penyelenggaraan Pengembangan Anak Usia Dini Holistik Integratif di satuan PAUD.

9. Peneliti merekomendasikan kepada peneliti selanjutnya untuk meneliti lebih dalam tentang context penyelenggaraan program Pengembangan Anak Usia Dini Holistik Integratif di satuan PAUD Kota Palembang, termasuk peran instansi instansi dalam upaya menyelenggarakan program Pengembangan Anak Usia Dini Holistik Integratif di satuan PAUD Kota Palembang.

\section{DAFTAR PUSTAKA}

Sudjana, Nana, 2002, Dasar-dasar Proses Belajar Mengajar, Bandung: Sinar Baru A1 Gensindo

Wonk, Willy. dan Andri Hakim. 2010. Dahsyatnya Hipnosis. Jakarta : Visi Media.

Dinas Pendidikan Kota Palembang. (2017). Dinas Pendidikan Kota Palembang.http://siaponline.com/palembang/\#!/sekolah.

Bappenas. (2013). Studi Strategi Pengembangan Anak Usia Dini di Indonesia. Jakarta: Bappenas.

Clements, D, H, Fuson, K, C, \& Sarama J. (2017). The research-based balance in early childhood mathematics: A response to Common Core criticisms. Early Childhood Research Quarterly : 150-165.

Creswell, J.W. (2012). Research Design Qualitative, Quantitative, and Mixed Methods Approaches. London. Sage Publication. 
Diana, M. F, Symon, D, \& Yurizal. (2011). Perbendaan Tumbuh Kembang Anak Pada Posyandu Yang Terintegrasi PAUD Dengan Yang Tidak Trintegrasi PAUD. Jurnal Kesehatan Masyarakat, 6(1): 10-15.

Direktorat Pengembangan Anak Usia Dini, Dirjen PAUD dan Pendidikan Masyarakat, Kemendikbud. (2015). Petunjuk Teknis Penyelenggaraan Pengembangan Anak Usia Dini Holistik Integratif Di Satuan PAUD. Jakarta : Kemendikbud.

Fatmawati. (2011). Pola Pengasuhan dan Perlindungan Anak di Taman Anak Sejahtera (TAS). Skripsi. Program Studi Kesejahteraan Sosial. Fakultas Ilmu Dakwah dan Ilmu Komunikasi UIN Syarif Hidayatullah Jakarta.

Handayani, A \& Munawar, M. (2011). Peningkatan Kualitas POS PAUD Melalui Pengembangan Program Holistik Integratif.Jurnal Penelitian PAUDIA, 1(1): 75-92.

Hartanti, R, D. (2012). Implementasi Program Pendidikan Anak Usia Dini (PAUD) Kelurahan Jepara Kecamatan Bubutan Kota Surabaya.

Husaini,Y. (2003). Rehabilitasi Dan Fleksibilitas Penggunaan Kms Perkembangan Motoric Kasar. Dalam http://www.google.com. Di akses Tanggal 17 Agustus 2017.

Kesumawati, R, Allen, M \& Sari, N. (2017). Pengantar Statistika Penelitian. Depok: Raja Grafindo Persada.

Kiam. (2014). Implementasi Kebijakan Program Pendidikan Non Formal Pada Pendidikan Anak Usia Dini (PAUD) Di Kecamatan Sintang. Jurnal Administrasi Publik dan Birokrasi Vol. 1 No. 1: 1-9.

Miles, M. B. \& Huberman, A. M. (1986). Qualitative Data Analysis: A Sourcebook of New Methods. California: SAGE Publications Inc.

Peraturan Presiden Republik Indonesia No 62 Tahun 2013 Pasar 3 Tentang Pengembangan Anak Usia Dini Holistik Integratif.

Rahardjo, B. (2006). Pendidikan Usia Dini Masih Esklusif: Peranan Keluarga Mendidik Anak Usia Dini. Kaltim Pos.

Sabarini, S, Zahraini, D. Ayu \& Dewi, A, C. (2013). Desain Pengembangan Anak Usia Dini Holistik Integratif Paud Non Formal (Penelitian Research and Development di Pos PAUD Mutiara Kelurahan Lamper Lor Kecamatan Semarang Selatan). Jurnal Penelitian PAUDIA. 2 (1): 105-126.

Siswanto, H. (2014). Permasalahan Pendidikan Dasar dan Pendidikan Anak Usia Dini. Cendekia, 8 (2): 137-150.

Slot, P L,. Leseman, P, P.M Verhagen, J, \& Mulder, H (2015) Associations between structural quality aspects and process quality inDutch early childhood education and care settings. Early Childhood Research Quarterly (33) : 64-76. 
Stufflebeam, D, L. (1985). Educational evaluation and decising making, Illionis : Hasca Illinois Pecocok Publicers Inc.

Tedjawati, J.M. (2011). Peran HIMPAUDI Dalam Pengembangan PAUD. Jurnal Pendidikan dan Kebudayaan. 17 (1): 123-133.

Unicef. (2012). Indonesia Laporan Tahunan 2012 United For Children. Jakarta : Unicef.

Unicef. (1998). Pendidikan dan Perkembangan Anak Usia Dini. Jakarta: Unicef. 